\title{
Electrochemical and Electrochromic Properties of Poly(4,4" dimethoxy 3'-methyl 2,2':5',2' terthiophene)
}

\author{
Bruna L. Dias ${ }^{a}$, Emerson M. Girotto ${ }^{*, b}$, Roberto de Matos ${ }^{b}$, Marcos J. L. Santos $^{b}$, \\ Marco-A. De Paoli ${ }^{c}$ and Wilson A. Gazotti ${ }^{\grave{\dagger}, a}$ \\ ${ }^{a}$ Laboratório de Ciências Químicas, Centro de Ciência e Tecnologia, Universidade Estadual Norte Fluminense, \\ Av. Alberto Lamego 2000, 28015620 Campos dos Goytacazes - RJ, Brazil \\ ${ }^{b}$ Departamento de Química, Universidade Estadual de Maringá, Av. Colombo 5790, 87020900 Maringá, PR - Brazil \\ ${ }^{c}$ Instituto de Química, Universidade Estadual de Campinas, CP 6154, 13084971 Campinas - SP, Brazil
}

Este trabalho descreve o estudo das propriedades eletroquímicas, espectroeletroquímicas e eletrocrômicas de filmes finos de poli(4,4" dimetoxi 3'-metil 2,2':5',2" tertiofeno). A voltametria cíclica in situ foi usada para estudar o efeito da temperatura sobre a eletropolimerização. As temperaturas utilizadas na deposição eletroquímica foram $-10,0,10,20$ e $40{ }^{\circ} \mathrm{C}$. Os resultados indicaram que a temperatura de eletropolimerização afeta diretamente o grau de ordenamento molecular do polímero. O tempo de resposta eletrocrômico foi de $0,8 \mathrm{~s}$ para clareamento e $0,3 \mathrm{~s}$ para escurecimento (para filmes sintetizados a $40{ }^{\circ} \mathrm{C}$, espessura de $60 \mathrm{~nm}$ ). Após 1400 ciclos eletrocrômicos, o contraste óptico a $570 \mathrm{~nm}$ diminuiu de 31 para 14\%. A eficiência eletrocrômica foi intensificada em função do número de ciclos eletrocrômicos. Este fato foi provavelmente causado pela diminuição da carga injetada, necessária para a mudança de cor, sugerindo que as perdas na eletroatividade estão associadas a sítios que não são responsáveis pela mudança de coloração.

This work describes the electrochemical, spectroelectrochemical and electrochromic properties of poly(4,4" dimethoxy 3'-methyl 2,2':5',2" terthiophene) thin films. The effect of temperature on the electropolymerization was studied by cyclic voltammetry measured in situ. The temperatures used were $-10,0,10,20$, and $40{ }^{\circ} \mathrm{C}$. Results indicate that the electropolymerization temperature directly affect the degree of chain organization. The optical response time for bleaching was $0.8 \mathrm{~s}$ and for coloring $0.3 \mathrm{~s}$ (for films synthesized at $40^{\circ} \mathrm{C}, 60 \mathrm{~nm}$ thick). After 1400 electrochromic cycles, the chromatic contrast at $570 \mathrm{~nm}$ changes from 31 to $14 \%$. The coloration efficiency was enhanced as a function of redox cycling. This was probably caused by a decrease in the injected charge necessary for the color change, suggesting that the electroactive losses occurring during the cycles are related to sites not responsible for electrochromic contrast.

Keywords: thiophene derivatives, electrochromic properties, electro polymerization, electrochromism, conducting polymer

\section{Introduction}

In recent years, intrinsically conducting polymers (ICP) have become an important class of materials, mainly due to their electric properties and potential technological applications. Polythiophenes and their derivatives are among the most important and most studied ICP. ${ }^{1}$ The considerable attention directed toward polythiophenes is due to the combination of their electrical properties,

\footnotetext{
*e-mail: emgirotto@uem.br

$\dagger$ Deceased
}

environmental stability and, mainly, structural versatility. ${ }^{2}$ Another important feature is their low band gap, which makes them good materials for electrochromic devices. ${ }^{3}$ These characteristics and the outstanding chemical stability of the polythiophenes were key properties that lead to considerable research development regarding their uses in electro optic, electroluminescent and electrochromic devices, ${ }^{4,5}$ photoswitches ${ }^{6}$ light emitting devices, LED, ${ }^{7,8}$ lasers, ${ }^{9,10}$ macromolecular electronic systems (diodes, transistors, etc.), ${ }^{11,12}$ and gas sensors. ${ }^{13,14}$

In addition to their low cost and easy preparation, polythiophene and its derivatives have been used to 
develop new electrochromic devices (ED). These ED are now applied in calculators, computers, car mirrors, clocks, intelligent and electrochromic windows and other equipment, which previously used liquid crystal displays. Electrochromism is a property of materials or systems that reversibly change color (optical absorption or reflection) in response to an applied external potential bias. Recently, research has sought a combination of attractive and stable existing electrochromes or new materials, contributing to the progress of electrochromic technology. Consequently, there is a need to develop new preparation methods, capable to produce significant modifications in the structure and properties of existing electrochromes to satisfy the specific demands of each new application.

An important development in the research for new thiophene derivative monomers was monomer ring functionalization at the 3 -position. ${ }^{15}$ The poly(3alkoxythiophenes), presenting high solubility, good electrical and optical properties are the most studied derivatives. ${ }^{16}$ In their optical and electrochemical studies on poly(3-alkoxythiophenes), Zotti et al. and Tourillon observed, in comparison with poly(3-alkylthiophenes), that the poly(3-alkoxythiophenes) possess a lower band gap and a lower oxidation potential, resulting in a polymeric material with high stability in the doped form. ${ }^{15,17}$

Substituted polythiophenes, such as poly(4,4"dimethoxy-3'-methyl-2,2':5',2"-terthiophene), pDMTT, and poly(4,4"-dipentoxy-3'-dodecyl-2,2':5',2"-terthiophene), pDDTT, have properties strongly dependent on the length of the alkoxy and alkyl substituent groups, changing their spectroelectrochemical and photoelectrochemical properties. According to Casalbore-Miceli et al., this thiophene class shows a strong dependence of the maximum absorbance wavelength and oxidation peak potential on the alkyl chain length. ${ }^{18}$ In another recent work, it was demonstrated that the maximum absorption wavelength of poly\{3-[12-( $p$-methoxyphenoxy)alkyl]thiophene also depends on the alkyl chain length of the substituted monomer. ${ }^{19}$

Aiming to contribute towards understanding how the synthesis method affects the electrochemical and electrochromic properties of substituted terthiophenes, the present work reports the electrochemical and electrochromic characterization of a polymer obtained from a terthiophene derivative, poly(4,4"-dimethoxy-3'-methyl$2,2^{\prime}: 5^{\prime}, 2^{\prime \prime}$-terthiophene), taking into consideration the synthesis temperature and the electrochromic stability. The coloration efficiency (electrochromic efficiency), color change response time, and write erase efficiency (optical contrast) were evaluated at $570 \mathrm{~nm}$.

\section{Experimental}

\section{Polymer synthesis}

All the reagents and solvents used in this work were from Aldrich Chemical. Films of pDMTT were electrochemically prepared by two cycles of cyclic voltammetry (CV), using a $3 \times 10^{-3} \mathrm{~mol} \mathrm{~L}^{-1}$ solution of 4,4"-dimethoxy-3'-methyl-2,2':5',2"-terthiophene (Figure 1) and a $0.1 \mathrm{~mol} \mathrm{~L}^{-1}$ solution of tetrabutylammonium perchlorate (TBAP) in an acetonitrile/dichloromethane (3:1 $\mathrm{v} / \mathrm{v})$ mixture. The potential was scanned between -0.2 and $1.0 \mathrm{~V}$ (vs. $\mathrm{Ag} \mid \mathrm{AgCl}$ ), with a scan rate of $20 \mathrm{mV} \mathrm{s}^{-1}$ and temperatures of $-10,0,10,20$, and $40^{\circ} \mathrm{C}$. Concerning the standard electrode potential deviations with temperature change, compensation was achieved by normalization procedures according to Ives and Janz. ${ }^{20}$ In this sense, all curves were normalized considering the equation derived by Bates and Bower, ${ }^{21}$ equation 1 , where $\mathrm{T}$ is the temperature $\left({ }^{\circ} \mathrm{C}\right)$ and $\mathrm{E}^{\circ}$ the reference electrode potential (V). However, even after these corrections, we observed that temperature change deviations were not significant, ranging from $+0.014 \mathrm{~V}\left(10^{\circ} \mathrm{C}\right)$ to $0.010 \mathrm{~V}\left(40{ }^{\circ} \mathrm{C}\right)$.

$\mathrm{E}^{\mathrm{o}}=0.23735-5.3783 \times 10^{-4} \mathrm{~T}-2.3728 \times 10^{-6} \mathrm{~T}^{2}$

The thicknesses of the deposited films were measured using a Tencor Alpha Step 200 Profilometer. The electrochemical experiments were carried out with an AUTOLAB potentiostat/galvanostat, model PGSTAT 30 (EcoChemie). A three electrode electrochemical cell with Pt sheets or ITO glass, (area $=1.0 \mathrm{~cm}^{2}$ and surface resistivity $20 \Omega /$ square) as working electrodes, $\mathrm{Pt}$ wire as counterelectrode and $\mathrm{Ag} \mid \mathrm{AgCl}$ as reference was used.

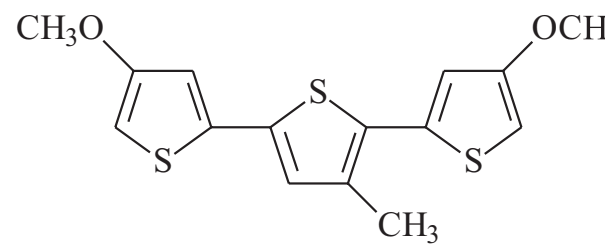

Figure 1. Structure of 4,4" dimethoxy 3'-methyl $2,2^{\prime}: 5^{\prime}, 2^{\prime \prime}$ terthiophene, DMTT.

Cyclic voltammetry and chronoamperometry

Films of pDMTT deposited on Pt were cycled in the -0.2 to $1.0 \mathrm{~V}$ (vs. $\mathrm{Ag} \mid \mathrm{AgCl}$ ) range, with a scan rate of $20 \mathrm{mV}$ $\mathrm{s}^{-1}$ using a Pt wire as counter electrode and a $0.1 \mathrm{~mol} \mathrm{~L}^{-1}$ free monomer solution of TBAP in acetonitrile. Chronoamperometric analyses were carried out with 
double potential steps of 0.2 and $0.9 \mathrm{~V}(v s . \mathrm{Ag} \mid \mathrm{AgCl}), 15 \mathrm{~s}$ each potential, at different temperatures.

\section{Spectroelectrochemistry}

Spectroelectrochemical measurements in the UV-VisNIR region were carried out using a $0.1 \mathrm{~mol} \mathrm{~L}^{-1}$ solution of TBAP in acetonitrile, an $\mathrm{AglAgCl}$ electrode as reference, ITO-glass sheets (area $1.0 \mathrm{~cm}^{2}$, surface resistivity $20 \Omega /$ square) as working electrodes and a Pt wire as counter electrode. The spectroelectrochemical measurements were carried out by placing the ITO modified electrodes in the sample compartment of a diode array spectrophotometer (Hewlett-Packard 8453) and switching the applied potential by using a MQPG 01 Microquímica potentiostat/galvanostat. The absorbance spectra of the pDMTT films were recorded at different polarization potentials: $0.2,0.1,0.0,0.2,0.4,0.6$, and $0.8 \mathrm{~V}$ (vs. $\mathrm{Ag} \mid \mathrm{AgCl})$.

\section{Electrochromic characterization}

The electrochromic properties of the pDMTT films deposited on ITO glass electrodes were evaluated through chronoamperometric experiments with simultaneous acquisition of the transmittance spectra using a $0.1 \mathrm{~mol}$ $\mathrm{L}^{-1}$ solution of TBAP in acetonitrile as electrolyte. The stability was tested by performing 1400 square wave double potential steps at -0.2 and $0.9 \mathrm{~V}$, for $15 \mathrm{~s}$ at each polarization. This chronoamperometric experiment permits evaluation of the life cycle and calculation of the coloration efficiency, response time and write erase efficiency. The transmittance data were recorded at $570 \mathrm{~nm}$.

\section{Results and Discussion}

\section{Synthesis of pDMTT}

The electrochemical deposition is a good alternative method for the preparation of conducting polymers. ${ }^{22,23}$ This method presents important advantages such as preparation of polymer films with controlled thickness, directly from the monomer solution. ${ }^{18}$ Moreover, the degree of polymerization can be improved by careful selection of the electropolymerization parameters. ${ }^{23-27}$

The electrosynthesized pDMTT films ( $c a .60 \mathrm{~nm}$ thickness) possess a fairly good visual surface homogeneity, independent of the substrate used (Pt or ITO). Figure 2 shows the cyclic voltammograms (second cycle) acquired during the synthesis of pDMTT onto Pt sheets at different synthesis temperatures. The monomer oxidation peak occurs between 0.82 and $0.84 \mathrm{~V}$. One interesting behavior is observed for the reduction signals, inset Figure 2. Starting from the curve for the synthesis at $10^{\circ} \mathrm{C}$ two peaks are observed, hereafter mentioned as peak I for the reduction process at $0.4 \mathrm{~V}$ and peak II for the reduction process at $c a .0 .1 \mathrm{~V}$. By increasing the temperature, peak I undergoes an intensity decrease with a simultaneous intensity increase for peak II, up to $20^{\circ} \mathrm{C}$. At $40{ }^{\circ} \mathrm{C}$ only one peak is observed, probably an average signal from peaks I and II. This result was quite reproducible for experiments done in triplicate. In addition, these changes do not take place during the first polymerization cycle. In spite of the voltammetric wave wideness, a certain degree of structural organization for the corresponding electroactive sites can be suggested. ${ }^{28-30}$ This fact is observed for the reduction process of peak I, at $-10^{\circ} \mathrm{C}$. Otherwise, an increase in the temperature leads to higher degree of structural organization for the electroactive sites related to the reduction process of peak II. Generally, a decrease in temperature improves the selectivity of the cation radical on the coupling site, but also decreases the coupling reaction rate. ${ }^{28-30}$ The results presented here indicated that increasing the temperature could not be established as a general tendency for increasing the degree of organization in these types of systems. In fact, based on the small changes in the reduction wave observed in the second polymerization cycle (inset Figure 2), by increasing the temperature not all molecular or structural sites are benefited in their degree of organization. However, one should keep in mind that detailed studies are necessary to derive final statements and to elucidate this hypothesis.

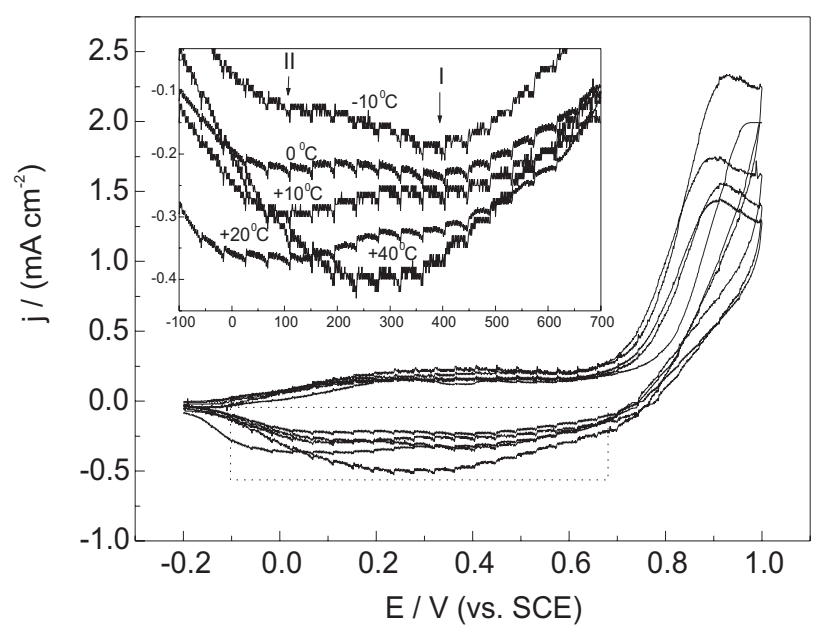

Figure 2. Voltammograms (second cycle) obtained for different films of pDMTT synthesized at different temperatures. Synthesis solution was $0.1 \mathrm{~mol} \mathrm{~L}^{1} \mathrm{TBAP}$ and $3 \times 10^{-3} \mathrm{~mol} \mathrm{~L}^{1}$ DMTT in acetonitrile/dichloromethane. 


\section{Electrochemical properties of pDMTT films}

Figure 3 displays a cyclic voltammogram of a freshly synthesized film of pDMTT. The occurrence of two redox peaks is observed, with oxidation and reduction couples at $0.16 / 0.075 \mathrm{~V}$ and $0.47 / 0.38 \mathrm{~V}$, respectively. This result reveals two processes (three species), but can not identify them. However, the formation of polarons and bipolarons is probably involved, but such result can not be referred only to the polaron bipolaron formation because during undoped to doped transition several effects give rise to redox and/or capacitive currents (mainly inhomogeneous structure of the film, crosslinking, microporosity, etc.).

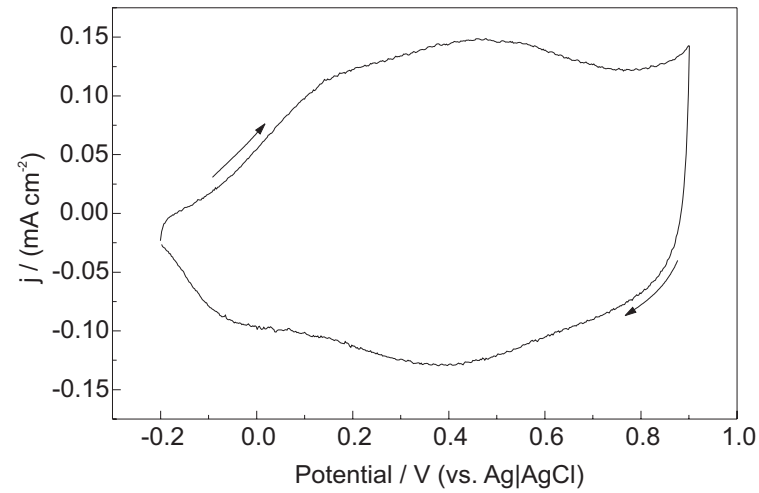

Figure 3. Cyclic voltammogram of an electropolymerized pDMTT film obtained in $0.1 \mathrm{~mol} \mathrm{~L}^{1}$ TBAP solution in acetonitrile.

Spectroelectrochemical and electrochromic properties of pDMTT films

A series of spectra in the visible-near infrared region, VIS-NIR, taken at successive doping levels is shown in Figure 4. The reduced form of pDMTT presents an absorbance maximum at $570 \mathrm{~nm}$, corresponding to an intense blue color. Thus, it was possible to calculate an energy gap of $c a .2 .2 \mathrm{eV}$. Increasing the degree of oxidation of pDMTT causes a gradual decrease in the absorbance intensity at $570 \mathrm{~nm}$ and, simultaneously, shifts the absorption band to longer wavelengths (hypsochromic shift), corresponding to the appearance of positive carriers and the formation of fully doped polymeric chains. As the doping level is increased, a sub-gap absorption grows at the expense of the $\pi-\pi^{*}$ transition, shown by the band located in the NIR region. ${ }^{3}$

The well-defined isosbestic point at ca. $660 \mathrm{~nm} \mathrm{(} c a$. $1.9 \mathrm{eV}$ ) implies the coexistence (and reversibility) of two regions on a doped pDMTT chain: regions where the $\pi-\pi *$ transition is almost unchanged (polarons), and localized regions surrounding the charge storage configuration (bipolarons). ${ }^{31}$ It is worth mentioning that

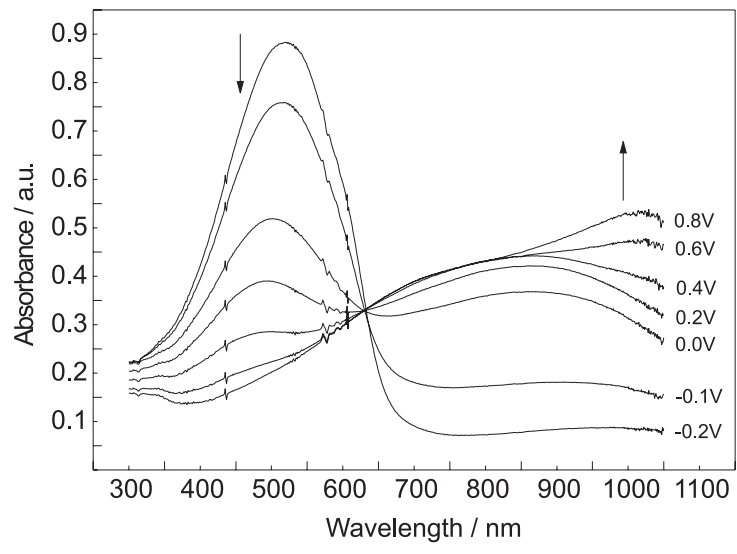

Figure 4. Vis-NIR spectra of pDMTT films polarized at different potentials. The film coverage was $1.0 \mathrm{~cm}^{2}$, electropolymerized at $40{ }^{\circ} \mathrm{C}$.

the undoped to polaron transition should be observed at lower wavelengths. This spectral variation, as a function of the oxidation state (Figure 4), corresponds to a change in the color of the material, from intense blue, in the reduced state, to transparent gray in the oxidized state. This color switching has an interesting feature that involves anti reflective applications. ${ }^{32}$ This behavior has also been reported for other polythiophene derivatives. ${ }^{33}$

The stability and the kinetics of the electrochromic process of pDMTT were determined by applying successive double potential steps, in chronoamperometric experiments $(0.9 \mathrm{~V}$ and $0.2 \mathrm{~V} v s$. $\mathrm{Ag} \mid \mathrm{AgCl})$, simultaneous with optical transmittance measurements at $570 \mathrm{~nm}$, Figure 5. The first electrochromic cycle indicates that coloring has a faster kinetics than bleaching. The optical response time for bleaching is $0.8 \mathrm{~s}$ and for coloring is $0.3 \mathrm{~s}$. After

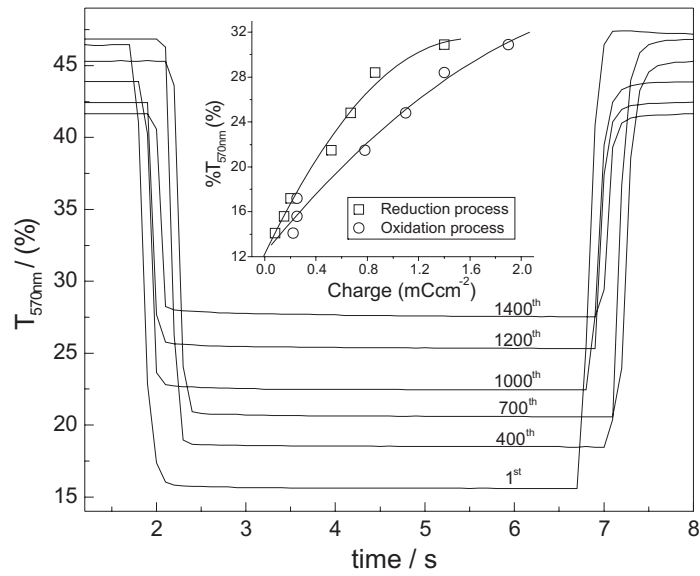

Figure 5. Optical contrast at $570 \mathrm{~nm}$ of a pDMTT film during double potential step experiments between -0.2 and $0.9 \mathrm{~V}$ ( $v s$. $\mathrm{Ag} \mid \mathrm{AgCl}$ ); instrumental time resolution was $0.05 \mathrm{~s}$. The film coverage was $1.0 \mathrm{~cm}^{2}$, electropolymerized at $40^{\circ} \mathrm{C}$. Inset: optical contrast versus charge for the reduction and oxidation processes, according to Table 1 . 
Table 1. Double potential step results for the pDMTT film in $0.1 \mathrm{~mol} \mathrm{~L}^{1} \mathrm{TBAP}$ acetonitrile solution

\begin{tabular}{lcccccccc}
\hline $\begin{array}{l}\text { Cycle } \\
\text { number }\end{array}$ & $\begin{array}{c}\mathrm{Q}_{\text {red }} \\
\left(\mathrm{mC} \mathrm{cm}^{-2}\right)\end{array}$ & $\begin{array}{c}\mathrm{Q}_{\text {oxi }} \\
\left(\mathrm{mC} \mathrm{cm}^{-2}\right)\end{array}$ & $\% \mathrm{~T}_{\text {red }}$ & $\% \mathrm{~T}_{\text {oxi }}$ & $\begin{array}{c}\Delta \% \mathrm{~T}_{\text {570nm }} \\
(\%)\end{array}$ & $\begin{array}{c}\eta_{\text {oxi }} \\
\left(\mathrm{cm}^{2} \mathrm{C}^{-1}\right)\end{array}$ & $\begin{array}{c}\eta_{\text {red }} \\
\left(\mathrm{cm}^{2} \mathrm{C}^{-1}\right)\end{array}$ \\
\hline 1 & 1.4 & 1.9 & 15.3 & 46.2 & 30.9 & 252.6 & 342.8 & 73.7 \\
200 & 0.86 & 1.4 & 18.5 & 46.9 & 28.4 & 288.6 & 469.8 \\
400 & 0.67 & 1.1 & 20.6 & 45.4 & 24.8 & 312.0 & 512.2 & 61.4 \\
700 & 0.52 & 0.78 & 22.4 & 43.9 & 21.5 & 374.6 & 561.9 & 60.9 \\
1000 & 0.20 & 0.25 & 25.4 & 42.6 & 17.2 & 898.3 & 1123 \\
1200 & 0.15 & 0.25 & 26.5 & 42.1 & 15.6 & 804.1 & 1340 \\
1400 & 0.080 & 0.22 & 27.6 & 41.7 & 14.1 & 814.7 & 2240 & 60.0 \\
\hline
\end{tabular}

$\mathrm{Q}_{\mathrm{oxi}}, \mathrm{Q}_{\text {red }}=$ oxidation and reduction charges. $\Delta \% \mathrm{~T}_{570 \mathrm{~nm}}=$ optical contrast at $570 \mathrm{~nm} . \eta_{\text {red }}, \eta_{\text {oxi }}=$ electrochromic efficiency for bleaching and coloring processes. $\mathrm{CE}=$ coulombic efficiency.

1400 electrochromic cycles, the chromatic contrast at $570 \mathrm{~nm}$ changes from $c a .31$ to $14 \%$, Table 1 . This was assigned to over oxidation and/or crosslinking processes occurring in the material, which affects its optical properties. ${ }^{34}$

Another operational requisite for electrochromes is a high electrochromic efficiency $\left(\eta\right.$, in $\left.\mathrm{cm}^{2} \mathrm{C}^{-1}\right)$. This parameter, also called coloration efficiency, is related to the injected charge necessary to produce the color change in the material (the electric charge must be minimized to save energy). ${ }^{35,36}$ The values obtained for electrochromic efficiency in this work, Table 1, are notably higher than values found in the literature for inorganic or organic electrochromes and devices. ${ }^{35,37}$ In our case, this is caused by the low charge required to promote the color change. In general, organic electrochromes exhibit a higher $\eta$ value than inorganic species, because the molar absorptivities of the former are usually higher. ${ }^{35}$ In addition, unlike previous papers, ${ }^{36}$ the values of $\eta$ increased as the number of redox cycles increased. Although the optical contrast and the injected charge decrease as the cycle number increases, the optical contrast seems to decrease in a lower ratio, as observed from the non-linear tendency of the $\Delta \% \mathrm{~T}$ $v s$. charge plot (inset of Figure 5). Considering that $\eta$ is a parameter correlating the optical contrast and the electric charge consumed at a given wavelength and supported by reproducible responses, the reported results suggest that the increasing $\eta$ is mainly due to a coulombic loss, which predominates over the optical losses and, moreover, this coulombic loss is probably related to non optically active sites.

\section{Conclusions}

Unlike previous results, the electropolymerization experiments reported here suggest that an increasing synthesis temperature could not be established as a general tendency for increasing the degree of organization in this type of polymer. This hypothesis can be extended to decreasing temperature trials. Although environmental stability after 1400 electrochromic cycles is not suitable for technological purposes, a fast response time was observed in comparison to other thiophene derivative polymers. The electrochromic behavior shows enhanced coloration efficiency as a function of redox cycling, caused by a decrease in the injected charge, necessary for the color change, which suggests that the electroactive losses occurring during the cycles are related to sites not responsible for the electrochromic change.

\section{Acknowledgements}

BLD, MJLS and RM thank CNPq and CAPES for fellowships, while EMG acknowledges PROFIX/CNPq project (541058/01-0). The authors gratefully acknowledge Dr. MC Gallazzi (Politecnico di Milano, Milan, Italy) for supplying the monomer.

\section{References}

1. Roncali, J.; Chem. Rev. 1992, 92, 711

2. Tourillon, G.; Garnier, F.; Lemaire, M.; J. Electroanal. Chem. 1982, 135, 173.

3. Pomerantz, M. In Handbook of Conducting Polymers; Skotheim, T. A.; Elsenbaumer, R. L.; Reynolds, J. R., eds.; Marcel Dekker: New York, 1998, ch. 11.

4. Roncali, J.; Chem. Rev. 1997, 97, 173.

5. Andersson, M. R.; Thomas, O.; Mammo, W.; Svensson, M.; Theander, M.; Inganäs, O.; J. Mater. Chem. 1999, 9, 1993.

6. Tsivgoulis, G. M.; Lehn, J. M.; Adv. Mater. 1997, 9, 39.

7. Andersson, M. R.; Berggren, M.; Gustafsson, G.; Hjertberg, T.; Inganäs, O.; Wennerström, O.; Synth. Met. 1995, 71, 2183.

8. Granström, M.; Polym. Adv. Technol. 1997, 8, 424.

9. Granlund, T.; Theander, M.; Berggren, M.; Andresson, M.; Ruzeckas, A.; Sundström, V.; Björk, G.; Granström, M.; Inganäs, O.; Chem. Phys. Lett. 1988, 288, 879. 
10. Mazeca, M.; Cittibabu, K. G.; Kim, J.; Kumar, J.; Jain, A.; Kim, W.; Tripathy, S. K.; Synth. Met. 1998, 98, 45.

11. Tsumura, A.; Ando, T.; Koezuka, H.; Appl. Phys. Lett. 1986, 49, 1210.

12. Bao, Z.; Lovinger, A. J.; Chem. Mater. 1999, 11, 2607.

13. De Melo, C. P.; Dos Santos, C. G.; Silva, A. M. S.; Dos Santos, F. L.; De Souza, J. E. G.; Mol. Cryst. Liq. Cryst. 2002, 374, 543.

14. Gallazzi, M. C.; Tassoni, L.; Bertarelli, C.; Pioggia, G.; Di Francesco, F.; Montoneri, E.; Sens. Actuators B 2003, 88, 178.

15. Zotti, G.; Gallazzi, M. C.; Zerbi, G.; Meille, S. V.; Synth. Met. 1995, 73, 217.

16. Yamamoto, T.; Sanechika, K.; Yamamoto, A. J.; J. Polym. Sci. Polym. Lett. 1980, 18, 9.

17. Tourillon, G. In Handbook of Conducting Polymers; Skotheim T. A.; Elsenbaumer, R. L.; Reynolds, J. R., eds.; Marcel Dekker: New York, 1986, p.293.

18. Casalbore-Miceli, G.; Camaioni, N.; Gallazzi, M. C.; Albertin, L.; Fichera, A. M.; Geri, A.; Girotto, E. M.; Synth. Met. 2002, 125, 307 .

19. Ribeiro, A. S.; Gazotti, W. A.; Santos Filho, P. F.; De Paoli, M.A.; Synth. Met. 2004, 145, 43.

20. Ives, D. J. G.; Janz, G. J.; Reference Electrodes. Theory and Practice, Academic Press: New York, 1961, p. 189.

21. Bates, R. G.; Bower, V. E.; J. Research Natl. Bur. Standards 1954, 53, 282.

22. Doblhofer, K.; Rajeshwar, K. In Handbook of Conducting Polymers; Skotheim, T. A.; Elsenbaumer, R. L.; Reynolds, J. R., eds.; Marcel Dekker: New York, 1998, ch. 25.

23. Zotti, G. In Handbook of Organic Conductive Molecules and Polymers; Nalwa, H. S., ed.; vol. 2. Wiley: New York, 1997, p. 137.

24. Roncali, J.; Yassar, A.; Garnier, F.; J. Chem. Soc., Chem. Сотmun. 1998, 581.

25. Glenis, S.; Horowitz, G.; Tourillon, G.; Garnier, F.; Thin Solid Films 1984, 111, 93.
26. Yassar, A.; Roncali, J.; Garnier, F.; Macromolecules 1989, 22, 804.

27. Camaioni, N.; Casalbore-Miceli, G.; Beggiato, G.; Cristani, M.; Summonte, C.; Thin Solid Films 2000, 366, 211.

28. Girotto, E. M.; Camaioni, N.; Casalbore-Miceli, G.; De Paoli M.-A.; Fichera, A. M.; Gallazzi, M. C.; J. Appl. Electrochem. 2001, 31, 335.

29. Casalbore-Miceli, G.; Camaioni, N.; Fattori, V.; Fichera, A. M.; Gallazzi, M. C.; Geri, A.; Girotto, E. M.; Giro, G.; Synth. Met. 2001, 121, 1575.

30. Girotto, E. M.; Casalbore-Miceli, G.; Camaioni, N.; De Paoli M.-A.; Fichera, A. M.; Belobrzeckaja, L.; Gallazzi, M. C.; J. Mater. Chem. 2001, 11, 1072.

31. Rughooputh, S. D. D. V.; Nowak, M.; Hotta, S.; Heeger, A. J.; Wudl, F.; Macromolecules 1987, 20, 212.

32. De Paoli M.-A.; Casalbore-Miceli, G.; Girotto, E. M.; Gazotti, W. A.; Electrochim, Acta 1999, 44, 2983.

33. Hotta, S. In Handbook of Organic Conductive Molecules and Polymers; Nalwa, H. S., ed.; Wiley: New York, 1997, vol. 2, p. 309.

34. Gazotti, W. A.; De Paoli, M-.A.; Casalbore-Miceli, G.; Geri, A.; Zotti, G.; J. Appl. Electrochem. 1999, 29, 753.

35. Monk, P. M. S.; Mortimer, R. J.; Rosseinsky, D. R.; Electrochromism: Fundamentals and Applications, VCH: Weinheim, 1995.

36. Gazotti, W. A.; Nogueira, A. F.; Girotto, E. M.; Micaroni, L.; Martini, M.; Neves, S.; De Paoli, M-A. In Handbook of Advanced Electronic and Photonic Materials and Devices; Nalwa, H. S., ed.; Academic Press: San Diego, 2001, vol. 10, ch. 2 .

37. Abraham, K.M. In Applications of Electroactive Polymers; Scrosati, B., ed.,. Chapman \& Hall: London, 1993, ch. 3; Scrosati, B. ibidem, ch. 7; Mastragostino, M. ibidem, ch. 8.

Received: October 14, 2004

Published on the web: May 18, 2005

FAPESP helped in meeting the publication costs of this article. 